\title{
Bacterial Separation and Community Diversity Analysis of Petroleum Contaminated Soil in Yumen Oilfield
}

\author{
YONGGANG WANG ${ }^{*}$, SHENGCAI DOU ${ }^{2}$, QINGFANG ZHANG ${ }^{2}$, \\ ABDOLGHAFFAR EBADI ${ }^{3}$, JIXIANG CHEN ${ }^{1,2 *}$, MOHSEN TOUGHANI ${ }^{4}$ \\ ${ }^{1}$ School of Energy and Power Engineering, Lanzhou University of Technology, Lanzhou 730050, China \\ ${ }^{2}$ School of Petrochemical Engineering, Lanzhou University of Technology, Lanzhou 730050, China \\ ${ }^{3}$ Department of Agriculture, Jouybar Branch, Islamic Azad University, Jouybar, Iran \\ ${ }^{4}$ Department of Fishery, Babol Branch, Islamic Azad University, Babol, Iran
}

\begin{abstract}
The problem of environmental pollution caused by the development and use of petroleum is increasingly obvious, which is a serious threat to human health. The use of microbial degradation to treat oil pollution is one of the environmentally effective, economical and practical methods.In order to explore the soil microbial diversity in the desert area of Northwest China, this paper analyzes the soil bacterial diversity of soil samples collected from different oil-contaminated areas in Yumen Oilfield for the oil pollution problem in the Yumen Oilfield in the northwest desert area, and selects the high efficiency through pure culture technology. Petroleum degradation bacteria, and research on the biological characteristics of degrading bacteria. The composition, abundance and diversity of bacterial communities in oil-contaminated soil in Yumen Oilfield were analyzed. The culturable bacteria in western oil-contaminated desert soil were separated by coating plate method. The bacterial morphology and 16S rRNA gene system development analysis were studied. The structure and diversity of bacterial community could be cultured, and the oil utilization and degradation ability of the strain could be analyzed. The microbial diversity of Yumen oil-contaminated desert soil was analyzed by Illumina Miseq high-throughput sequencing. Through research, it is found that there are abundant bacterial groups in the oil-contaminated desert soil, and there are obvious diversity. The genetic material in the variable regions of the six soil samples detected a total of 3943 OTU at 97\% similarity level, and obtained the soil microbial community. Doors, 48 classes, 78 orders, 179 families and 471 genera, including most common high-efficiency petroleum-degrading bacteria. Petroleum hydrocarbon pollution can change the microbial diversity and community structure of the original soil. The size of microbial diversity in the six soil samples is $B 2>A 1>B 1>A 2>C 1>C 2$, the diversity of $B 2$ is the highest, the diversity of $C 2$ is the lowest, and the microbial diversity differed greatly between groups, and there was no difference in the group. Among the dominant bacteria isolated from contaminated soil, 8 strains of oil have a degradation rate of more than $30 \%$, including the species of the genus Rhodococcus and Pseudomonas. Soil desertification in western China has a great impact on the local ecological environment. Studying the microbial diversity of desert soils and separating highefficiency petroleum-degrading strains is of great significance for strengthening the ecological restoration of oil-contaminated environment in desert areas.
\end{abstract}

Keywords: oil pollution, microbial diversity, $16 S$ rRNA, high-throughput sequencing, functional expression

\section{Introduction}

As an important place for soil microbial exchange, energy exchange and information exchange, soil ecosystems connect various animals, plants and microorganisms in the soil environment and make them a whole. Among them, soil microbes are one of the main members involved in the carbon cycle and nitrogen cycle [1-2], and soil microbes respond quickly to environmental changes caused by oil

*email:Y.wang300@yahoo.com, chenjixiang@lut.cn 
pollution [3-5]. With the development of China's economy, oil consumption is increasing, and environmental pollution problems caused by oil development and utilization are becoming more and more obvious, which seriously threatens human health. Oil pollution has become one of the most serious environmental problems in the world [6-8]. When the rate of oil contaminants entering the soil or the amount of pollutants exceeds the rate and ability of the soil to self-clean, it will cause pollution and damage to the soil environment [9]. Oil pollution is a global topic. There are abundant microbial resources in the soil environment, and it is also one of the important sources of petroleum degradation microorganisms. Oil pollution leads to changes in soil physical and chemical properties, and also causes changes in soil microbial community structure and diversity [10,11]. A large amount of petroleum pollutants entering the soil will cause soil odor, affecting the permeability and hydrophobicity of the soil, and thus seriously affecting the water holding capacity of the soil and the circulation of nutrients in the soil. The entry of petroleum pollutants into the soil will also lead to a decrease in soil available phosphorus and available nitrogen, a change in carbon to nitrogen ratio $(\mathrm{C} / \mathrm{N})$, a carbon/phosphorus ratio $(\mathrm{C} / \mathrm{P})$, and a decrease in soil $\mathrm{pH}$ and conductivity [12].

The entry of petroleum contaminants into the soil will also pose a serious threat to plants for examples drug residues [13-16]. Leakage of petroleum contaminants can affect the germination rate of plants, making their growth retardation, ability to resist pests and diseases, and even the yield will be significantly reduced [17]. After the petroleum hydrocarbon pollutants enter the soil, the original structure and physical and chemical properties of the soil will change, resulting in changes in the types and quantities of the original microorganisms in the soil, thus affecting the microbial community structure and the function of the entire ecosystem [18]. The entry of petroleum pollutants into the soil can also cause serious harm to human health and even threaten the living environment of human beings. It can be enriched in animals and plants through the food chain [19-22], endangering the health of animals and plants. Some petroleum pollutants that are difficult to degrade and absorb can enter the atmospheric environment by evaporation, and enter the groundwater through runoff and infiltration, causing groundwater pollution and affecting the soil ecosystem [23,24].

Removing oil pollution from the soil is a long and difficult process [25]. There are three main methods for remediation of petroleum-contaminated soils: physical restoration, chemical remediation, and bioremediation. Physical and chemical repair costs are high, and it is easy to cause secondary pollution, and can not achieve complete repair [26]. Among the various repair methods, bioremediation is considered to be an efficient, economical, and environmentally sound solution, and has been shown to have a good repair effect on oil-contaminated soil in several laboratory and field studies [27,28]. Bioremediation is an effective choice for oil-contaminated soil remediation, with minimal damage to the soil environment [29]. In the field of ecological environmental protection, due to the low cost of bioremediation, obvious repair effect, and no secondary pollution [30,31], it is considered to be the most promising, most valuable and most vital restoration method [32-34]. Studies have found that rare microorganisms (low-abundance microbes) in oil-contaminated soils may be involved in regulating ecosystem function and stability [35] and contain a large number of functional genes involved in alkane degradation [36]. Therefore, the use of specific microorganisms to repair petroleum-contaminated soils has become the most valuable and important bioremediation tool in applied microbiology research [37]. The development of high-throughput sequencing has enabled the identification of soil microbial communities [38], which has greatly helped us understand microbial communities and diversity [39]. In the process of oil-contaminated soil remediation, the focus of research remains on species diversity, microbial structural diversity and functional diversity [40-43]. In this paper, high-throughput sequencing was used to analyze the composition, abundance and diversity of microbial communities in desert oil-contaminated soils in northwest China. The culturable bacteria in western oil-contaminated desert soils were separated by coating plate method, and the morphology and 16S rRNA gene system were developed. Analyze and study the structure and diversity of cultivating bacterial communities, and analyze the oil utilization and degradation ability of 
the strains. The purpose is to provide theoretical basis and strain resources for bioremediation of petroleum-contaminated soil in desert areas.

\section{Materials and methods}

\subsection{Sampling Area Overview and Sample Collection}

Yumen Oilfield is located in Yumen City, Gansu Province. The geographical coordinates of Yumen City are between $96^{\circ} 15^{\prime} \sim 98^{\circ} 30^{\prime}$ east longitude and $39^{\circ} 40^{\prime} \sim 41^{\circ} 00^{\prime}$ north latitude. It is a continental temperate arid climate with an average elevation of 2,500 3,500 m, less precipitation, large evaporation, long sunshine, annual average temperature of $6.9{ }^{\circ} \mathrm{C}$, annual sunshine duration of $3166.3 \mathrm{~h}$, average frost-free period of $135 \mathrm{~d}$, annual average precipitation of $63.3 \mathrm{~mm}$, evaporation of $2952 \mathrm{~mm}$, annual average wind speed of $4.2 \mathrm{~m} / \mathrm{s}$.

The oil-contaminated soil samples were taken from different areas of the oil-contaminated area with a sampling depth of about $10 \mathrm{~cm}$. The samples were collected and sealed in a sterile bag. The soil samples collected were recorded as A-like (A1 \& A2), B-like (B1 \& B2), and C-like (C1 \& C2). After a part of the soil sample was air-dried, its physical and chemical properties were determined, and another part of the soil sample was stored in a $-80^{\circ} \mathrm{C}$ refrigerator for DNA extraction. Determination of petroleum hydrocarbon content by ultrasonic Soxhlet extraction [44]. Soil physical and chemical properties include: $\mathrm{pH}$, conductivity, total nitrogen (TN), available nitrogen (AN), total phosphorus (TP), available phosphorus (AP), total potassium (TK), available potassium (AK), and soil organic matter. The above properties were determined by standard soil assay [45].

\subsection{Extraction and PCR Amplification of Total DNA from Soil}

Weigh $200 \mathrm{mg}$ of soil samples, place them in a sterile $2 \mathrm{~mL}$ centrifuge tube, add $1 \mathrm{~mL}$ of $70 \%$ ethanol, mix by shaking, centrifuge at $10,000 \mathrm{r} / \mathrm{min}$ for $3 \mathrm{~min}$ at room temperature, and discard the upper layer of liquid. Add $1 \times$ phosphate buffer (PBS), mix by shaking, centrifuge at 10,000 r/min for $3 \mathrm{~min}$ at room temperature, and discard the upper layer of liquid. Invert the $2 \mathrm{~mL}$ centrifuge tube onto blotting paper for $1 \mathrm{~min}$ until no liquid has flowed out. The sample tube was placed in an oven at 55 ${ }^{\circ} \mathrm{C}$ for 10 min until the residual alcohol was completely evaporated. The extraction procedure of the total DNA of the soil refers to the kit instruction manual of the OMEGA kit E.Z.N.ATM Mag-Bind Soil DNA Kit (website link: http://www.omegabiotek.com.cn/Product/109.html).

The extracted sample DNA was subjected to two rounds of amplification, and the Qubit 2.0 DNA detection kit was used to accurately quantify the genomic DNA in the first round of amplification to determine the amount of DNA to be added by the PCR reaction. The primers used for PCR have been fused to the V3-V4 universal primer of the Miseq sequencing platform (341F primer: CCCTACACGACGCTCTTCCGATCTG (barcode) CCTACGGGNGGCWGCAG; 805R primer: GACTGGAGTTCCTTGGCACCCGAGAATTCCAGACTACHVGGGTATCTAATCC). Illumine bridge PCR compatible primers were introduced during the second round of amplification. The PCR reaction system was as follows: $15 \mu \mathrm{L}$ of $2 \times$ Taq master Mix; $1 \mu \mathrm{L}$ of Bar-PCR primer F $(10 \mu \mathrm{M}) ; 1$ $\mu \mathrm{L}$ of Primer R $(10 \mu \mathrm{M}) ; 10-20 \mathrm{ng}$ of Genomic DNA, Add $\mathrm{H}_{2} \mathrm{O}$ to a total volume of $30 \mu \mathrm{L}$.

\subsection{High-throughput Sequencing}

The amplification results were sequenced by Illumine MiSeq sequencer, and the data were separately filtered, quality control and bioinformatics analysis [46,47], completed by Sangon (Shanghai) Bioengineering Co., Ltd.

\subsection{Data Statistics and Bioinformatics Analysis}

The basic physical and chemical properties of petroleum-contaminated soil samples were analyzed using SPSS 17.0 (Statistical Product and Service Solution) software. Using QIME (Quantitative Insight Microbial Ecology) software [48], according to the similarity of sequences, the sequence of 97\% similarity is defined as an OTU [49], thus dividing the sequence into multiple operational taxon. 
The classification information for each OTU was obtained by searching for the nearest relative species, selecting an OTU with $97 \%$ similarity to generate the desired dilution curve, and performing an Alpha diversity index analysis. Data processing, bacterial community distribution, principal component analysis and clustering were performed using EXCEL, heat map and related clusters, respectively. Finally, using the PICRUSt (community phylogenetic survey by reconstructing unobserved state) software, the existing community composition data is compared with a known reference gene database, and the microbial abundance data in the original data is corrected to predict the community. The metabolic function of the sample.

\section{Results and discussions}

\subsection{Physical and Chemical Properties of Soil}

The basic physical and chemical properties of the six soil samples used in this experiment are shown in Table 1 . The results showed that the soils of 6 plots were alkaline $(\mathrm{pH}>8)$, and there were significant differences in TPH and EC among 6 oil contaminated soil samples $(\mathrm{p}<0.05)$. According to the data in the table, there were significant differences in TN, AN, TP, TK and AK of soil samples from different sampling sites ( $<<0.05)$. There was no significant difference between AP and SOM ( $p>0.05$ ), which may be caused by the change of microbial activity in soil.

Table 1. The physical and chemical basic properties of the soil samples

\begin{tabular}{|c|c|c|c|c|c|c|}
\hline & Items & A1 & B1 & B2 & C2 & \\
\hline TPH (\%) & $0.33 \pm 0.07 \mathrm{c}$ & $0.38 \pm 0.08 b c$ & $0.46 \pm 0.057 \mathrm{~b}$ & $0.617 \pm 0.04 a$ & $0.13 \pm 0.046 \mathrm{~d}$ & $0.293 \pm 0.081 \mathrm{c}$ \\
\hline $\mathrm{pH}$ & $8.38 \pm 0.42 \mathrm{c}$ & $8.27 \pm 0.15 \mathrm{a}$ & $8.35 \pm 0.22 \mathrm{a}$ & $8.45 \pm 0.3 \mathrm{a}$ & $8.45 \pm 0.20 \mathrm{a}$ & $8.72 \pm 0.17 \mathrm{a}$ \\
\hline $\mathrm{EC}$ (us/cm) & $1480 \pm 75.2 b$ & $1702 \pm 31.9 \mathrm{a}$ & $1363.16 \pm 89.1 \mathrm{c}$ & $1168.4 \pm 49.7 \mathrm{~d}$ & $1814.5 \pm 79.06 \mathrm{a}$ & $1785.4 \pm 48.0 \mathrm{a}$ \\
\hline $\mathrm{TN}(\mathrm{g} / \mathrm{kg})$ & $0.33 \pm 0.02 b c$ & $0.40 \pm 0.049 b$ & $0.28 \pm 0.055 c$ & $0.29 \pm 0.026 \mathrm{c}$ & $0.54 \pm 0.096 a$ & $0.51 \pm 0.047 \mathrm{a}$ \\
\hline AN $(\mathrm{mg} / \mathrm{kg})$ & $32.92 \pm 1.7 \mathrm{~d}$ & $38.23 \pm 0.6 \mathrm{~d}$ & $35.16 \pm 6.53 \mathrm{~d}$ & $52.04 \pm 5.77 \mathrm{c}$ & $61.42 \pm 2.66 \mathrm{~b}$ & $70.43 \pm 6.61 \mathrm{a}$ \\
\hline TP $(\mathrm{g} / \mathrm{kg})$ & $0.19 \pm 0.01 b c$ & $0.21 \pm 0.03 \mathrm{abc}$ & $0.16 \pm 0.04 \mathrm{~cd}$ & $0.14 \pm 0.02 \mathrm{~d}$ & $0.23 \pm 0.016 \mathrm{ab}$ & $0.24 \pm 0.017 \mathrm{a}$ \\
\hline $\mathrm{AP}(\mathrm{mg} / \mathrm{kg})$ & $2.5 \pm 0.13 \mathrm{~b}$ & $2.95 \pm 0.10 \mathrm{~b}$ & $2.58 \pm 0.34 \mathrm{~b}$ & $2.43 \pm 0.74 \mathrm{~b}$ & $7.29 \pm 0.39 a$ & $7.75 \pm 0.43 a$ \\
\hline TK $(\mathrm{g} / \mathrm{kg})$ & $24.5 \pm 1.24 \mathrm{~d}$ & $27.65 \pm 1.38 c$ & $23.07 \pm 0.69 \mathrm{de}$ & $20.76 \pm 1.86 \mathrm{e}$ & $31.20 \pm 2.30 \mathrm{~b}$ & $33.92 \pm 0.36 \mathrm{a}$ \\
\hline AK $(\mathrm{mg} / \mathrm{kg})$ & $29.69 \pm 1.5 \mathrm{c}$ & $33.97 \pm 0.9 \mathrm{c}$ & $32.78 \pm 7.75 \mathrm{c}$ & $46.61 \pm 6.86 \mathrm{~b}$ & $88.54 \pm 9.1 \mathrm{a}$ & $87.56 \pm 3.30 \mathrm{a}$ \\
\hline SOM $(\mathrm{g} / \mathrm{kg})$ & $13.7 \pm 0.70 \mathrm{a}$ & $15.35 \pm 1.0 \mathrm{a}$ & $14.82 \pm 2.99 \mathrm{a}$ & $13.84 \pm 2.86 \mathrm{a}$ & $8.203 \pm 0.30 b$ & $7.19 \pm 0.12 b$ \\
\hline
\end{tabular}

Note: the codes A1, A2, B1, B2, C1, and C2 in the table represent six different sampling sites (the same as below). Each process was repeated three times, and all the data was analyzed by ANOVA. After the same line of data, the uppercase letters were the same, and there was no significant difference between the two groups ( $p>0.05)$. If there were different continuous lowercase letters after the data there were significant differences among the groups $(\mathrm{p}<$ $0.05)$.

\subsection{Study on Degradation Characteristics of Petroleum Hydrocarbons}

In the medium with oil as the sole carbon source and energy source, most of the strains could grow well, including Colorless bacteria YM01 and YM46; Staphylococcus YM02; Rhodococcus YM05,YM09 and YM43; Pseudomonas aeruginosa YM15,YM22 and YM36; Serreella YM20; YM25; Oligotrophic bacteria YM28; Acinetobacter YM29; YM32 and Micrococci YM39. Through the study of oil degradation, it was found that the oil degradation rate of 8 strains was more than 30\%, the degradation rates of YM43, YM32, YM29, YM09, YM39, YM15, YM25 and YM20, were $55.47 \%, 45.91 \%, 39.80 \%, 38.85 \%, 35.75 \%, 33.84 \%, 30.98 \%$ and $30.55 \%$, respectively. The 
phylogenetic analysis of these eight strains with high oil degradation rate was carried out, and the results are shown in Figure 1.

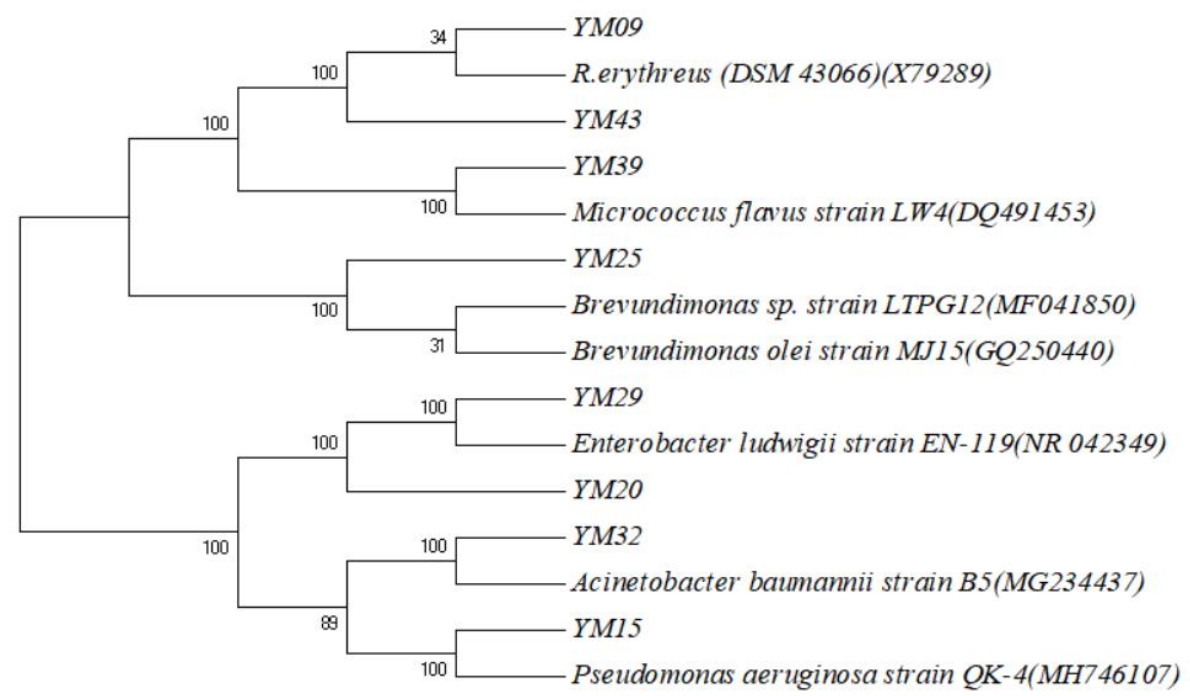

Figure 1. Phylogenetic trees based on multiple alignments of strains $16 \mathrm{~S}$ rDNA Note: the GenBank login number is in parentheses; the number at the branch point is the percentage of the self-developed value; and the line segment 0.02 is the nucleotides replacement rate.

\subsection{Diversity Analysis of Microbial Communities}

Microbial diversity was studied in community ecology. Alpha diversity analysis (single sample diversity) could reflect the abundance and diversity of microbial communit, including a series of statistical analysis indexes to estimate the species abundance and diversity of environmental community. By drawing sparse curves, we can also determine whether the current ranking depth of each sample is sufficient to reflect the microbial diversity contained in the community samples. The dilution curve is shown in Figure 2 (take the Shannon index as an example).

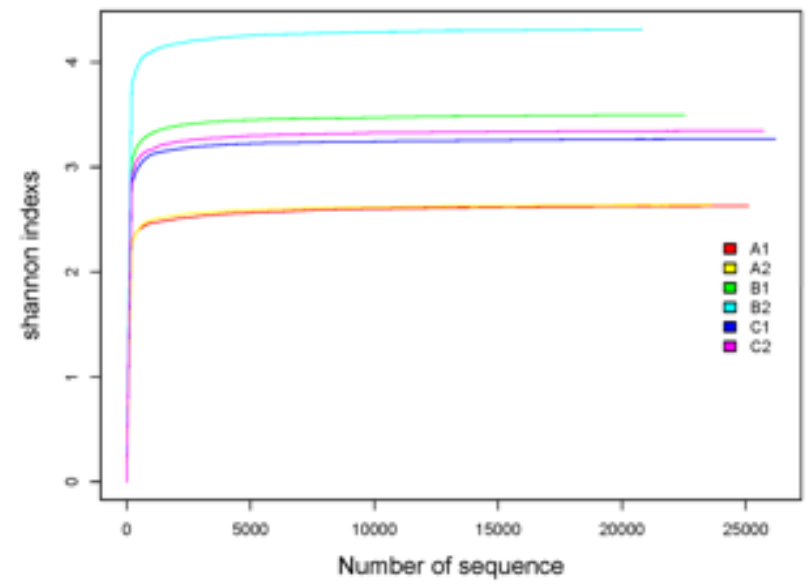

Figure 2. The shannon Rarefraction

In Figure 2, the number of the extracted sequences is taken as the transverse coordinate and the corresponding shannon index as the longitudinal coordinate. The results of graph analysis and sequencing show that when the sequencing sequence reaches a certain length, the curve tends to be stable, which indicates that the sequencing data of the sample is reasonable and can reflect most of the microbial information in the sample, and the obtained data have high reliability. 
Table 2. Diversity index

\begin{tabular}{|c|c|c|c|c|c|c|}
\hline Sample & OTU number & $\begin{array}{c}\text { Shannon } \\
\text { index }\end{array}$ & $\begin{array}{l}\text { ACE } \\
\text { index }\end{array}$ & $\begin{array}{l}\text { Chao1 } \\
\text { index }\end{array}$ & Simpson & Coverage/\% \\
\hline $\mathrm{A} 1$ & 714 & 2.63 & 870.79 & 804.07 & 0.19 & 99 \\
\hline $\mathrm{A} 2$ & 625 & 2.64 & 774.97 & 728.64 & 0.19 & 99 \\
\hline B1 & 685 & 3.50 & 911.19 & 836.08 & 0.10 & 99 \\
\hline B2 & 788 & 4.31 & 987.98 & 896.04 & 0.03 & 99 \\
\hline $\mathrm{C} 1$ & 577 & 3.27 & 790.82 & 731.49 & 0.12 & 99 \\
\hline $\mathrm{C} 2$ & 554 & 3.35 & 720.35 & 691.79 & 0.11 & 99 \\
\hline
\end{tabular}

The Chao1/ACE index is mainly concerned with the species richness information of the sample, the Simpson/Shannon mainly reflects the species richness and evenness, and the coverage reflects the low abundance OTU coverage of the sample (Table 2). Chao1 and ACE analysis showed that the species were sample B > sample A > sample C. Shannon and Simpson analysis showed that the community diversity of sample B was the highest and that of sample A was the lowest. Based on the number and relative abundance of OTU, the Shannon index of bacterial population in different samples was significantly different, in which sample B2 was the highest and sample A1 was the lowest. Through the analysis, the OTU coverage rate of each sample is $99 \%$, which shows that the results can reflect the true composition of bacterial community in the measured samples.

Rank-abundance are a way to analyze diversity. The construction method is to count the number of sequences contained in each OTU in a single sample, sort OTUs from large to small order according to abundance (the number of sequences contained), then take the OTU level as the abscissa, and take the number of sequences contained in each OTU (the relative percentage content of sequences in OTU can also be used) as the ordinate coordinates. The Rank bounce curve is used to simultaneously interpret two aspects of sample diversity, namely the abundance and uniformity of the species contained in the sample. The abundance of species is reflected by the length of the curve on the horizontal axis. The uniformity of species composition is reflected by the shape of the curve.

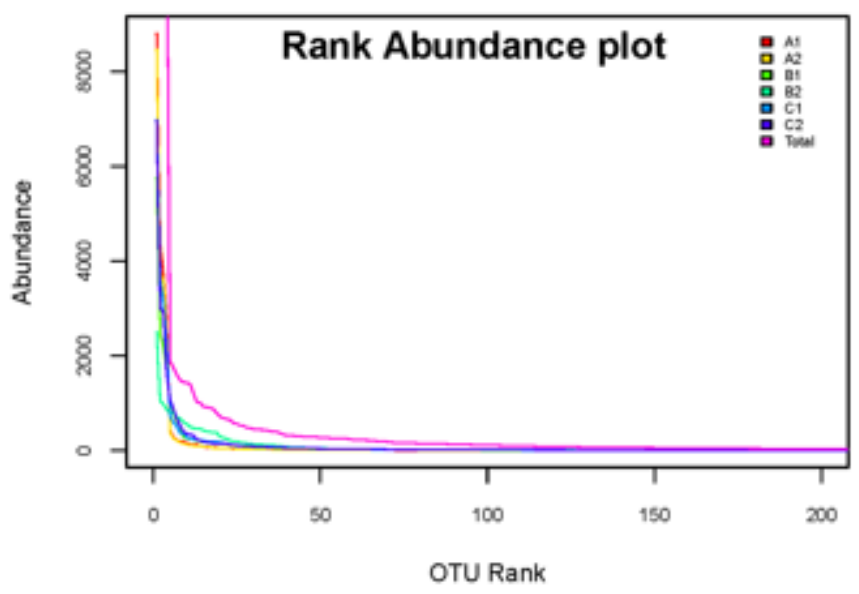

Figure 3. Rank

Abundance Curve

As shown in Figure 3, the relationship between the width and size of sample A, sample B, and sample $\mathrm{C}$ is sample $\mathrm{C}>$ sample $\mathrm{B}>$ sample $\mathrm{A}$, indicating that sample $\mathrm{C}$ has the most abundant components, sample B is the second and sample A is the smallest. From the curve shape, the smoother the curve is, the more uniform the species composition is. When the abundance value of sample $A$ is more than 4000, the abundance value of sample B is between $1000 \leq 6000$, and the abundance value of sample $\mathrm{C}$ is between $3000 \leq 7000$, the rank abundance curve of the sample is smoother, which indicates that the uniformity of species in the sample is higher. In the range of abundance less than 
1000 , the curves of six soil samples showed different bends, indicating that the lower the abundance value of species, the smaller the uniformity of species.

\subsection{OTU Distribution Wayne Diagram}

The Wayne diagram can intuitively show the number of common and unique OTU in the sample, thus reflecting the similarity and overlap of OTU composition between the samples. As can be seen in Figure 4, a total of 2744 OTU are detected in the oil-contaminated sample, and the samples A1, A2, B1, B2, C1 and C2 contain 714, 625, 685, 788, 577 and 554 OTU, respectively. The sample A1 contains 157 OTU; The sample A2 contains 105 OTU; the sample B1 contains 139 OTU; the sample B2 contains 225 OTU; the sample C1 contains 63 OTU; the sample C2 contains 61 OTU; 91 OTU in 6 petroleum-contaminated soil samples. Through the analysis, it is found that the OTU number of sample A and sample C are about the same, and the number of OTU contained in sample B is quite different, which indicates that the composition of bacterial population in different samples is different and has preference bacterial population.

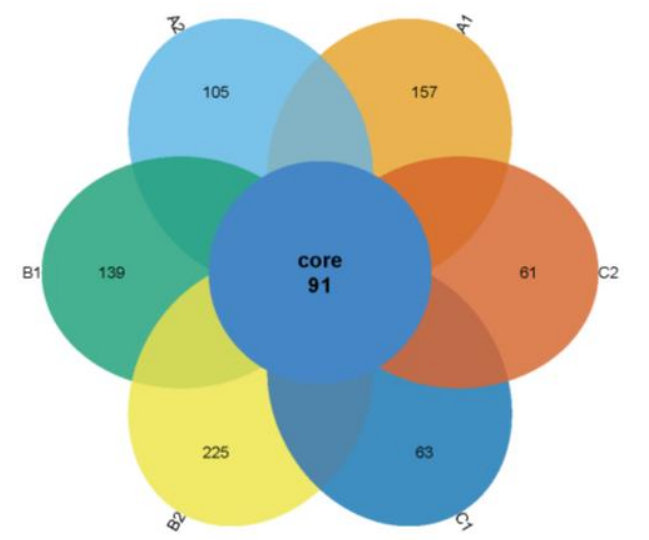

Figure 4. Wayne diagram of OTU sample distributions

\subsection{Analysis of Microbial Community Structure}

Based on the community classification composition of each soil sample, the community structure distribution map of the genus level sample was drawn. The transverse axis is the number of each sample, each column diagram represents a sample, and each genus is distinguished by color. The larger the proportion interval is, the higher the relative abundance of each genus is. As can be seen from Figure 5, the dominant species in the soil sample are Bacillus, Lactococcus, Oceanobacillus, and Enterococcus. The four dominant bacteria accounted for a large proportion in 6 soil samples, in which sample A was more than $80 \%$, and the difference in sample B was obvious, in which B1 accounted for about $60 \%$, B2 was less, about $30 \%$, and sample $\mathrm{C}$ was close to $60 \%$. In sample A and sample $\mathrm{C}$, the species with low richness were evenly distributed, while those with low richness in sample B were not evenly distributed.
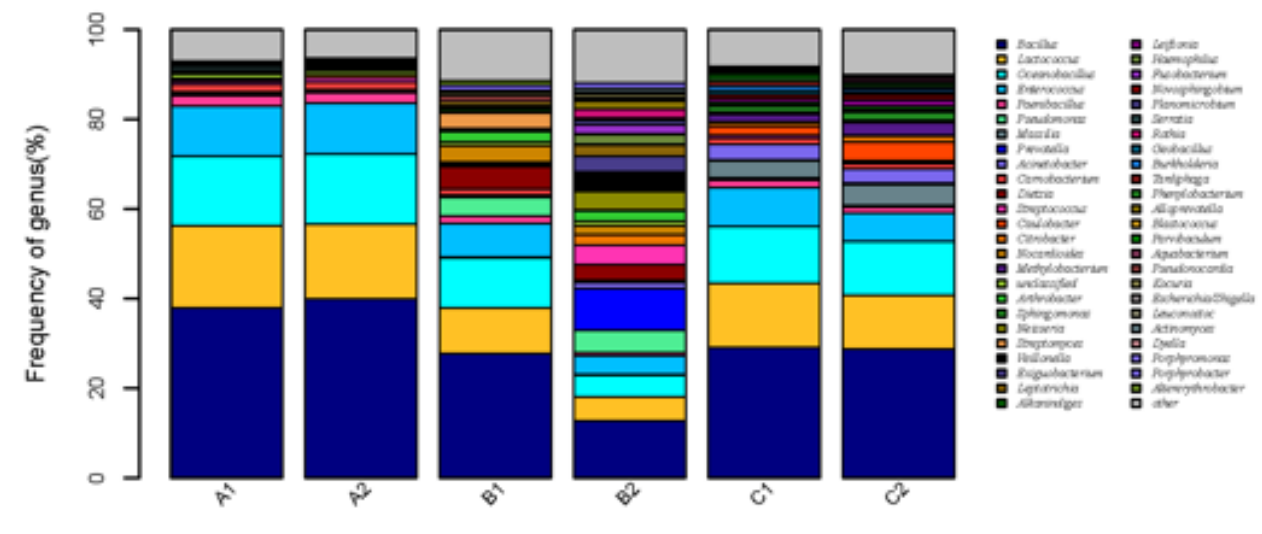

Figure 5. Distribution Map of Community Structure of all Samples at Genus Level 
From the analysis of the species classification box (Figure 6), the dominant bacteria in the six soil samples were mainly Firmicin, Proteobacteria, Acinetobacter, Bacteroides and Fusobacterium. Among them, the dominant species of Firmicin include Bacillus, Lacococcus, Oceanobacillus, Enterococcus, Paenibacillus, Streptococcus and Planomicrobicum; the dominant bacteria of Proteobacteria are Pseudomonas, Militaria, Acinetobacter, Caulobactter, Citrobacter, Methylobacterium, Sphingomonas, and Alkandines; the dominant bacteria of Acinetobacter include Dietzia, Nocardia, Arthorobacter, Streptomyces, Leifsonia and Rothia; the dominant species of Bacteroides are mainly Prevotella; and the dominant bacteria of Fusobacterium are mainly Fusarium.

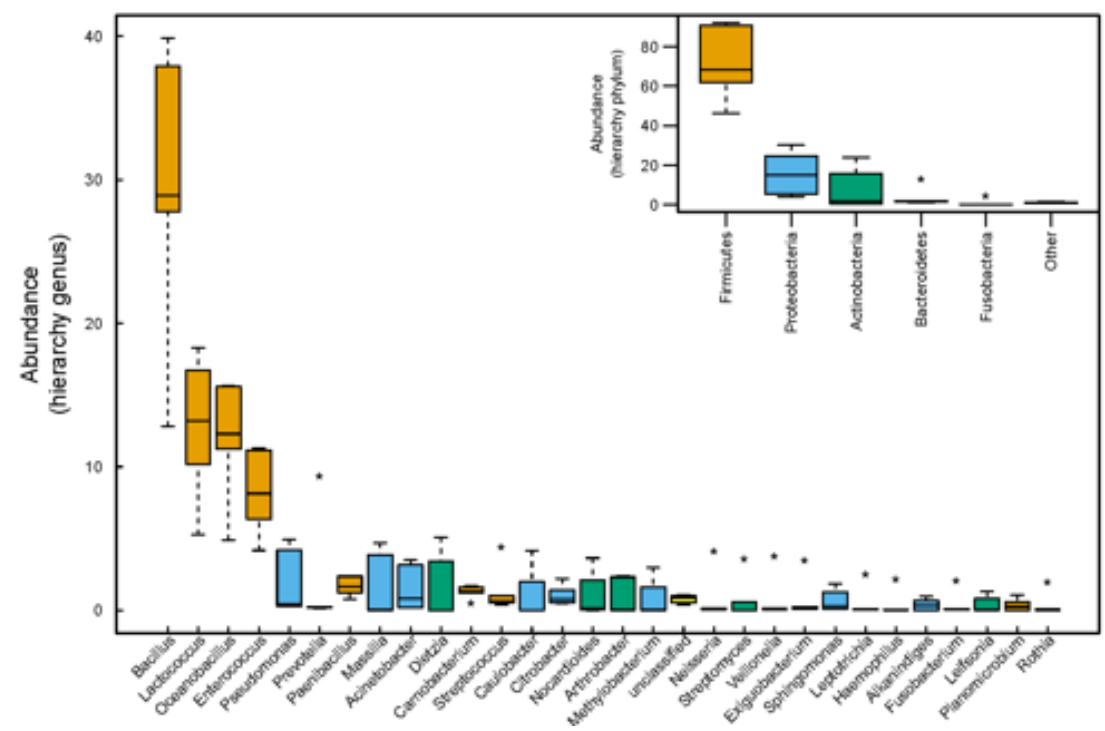

Figure 6. Analysis Map of Species Classification Box Line

\subsection{PCA Analysis Based on OTU (3D)}

Principal Component Analysis (PCA) is a technique to simplify the data set in the multivariate statistical analysis. It can intuitively reflect the characteristics of the microbial community in different samples and can be used to explain the diversity of the microbial community. The principal coordinate analysis of the soil microorganism is shown in Figure 7. The different colors in the figure represent samples in different samples or in different groups, the higher the similarity between the samples, the more the sample is in the graph. The contribution rate of the main component 1 (PC1), the main component 2 (PC2) and the main component 3 (PC3) is 97\%, 2\% and 1\%, respectively. The cumulative contribution rate is $100,97,2$ and $1 \%$, respectively. As can be seen from the figure, the sample A has the highest similarity, the sample $\mathrm{C}$ is the second, and the sample B is the worst.

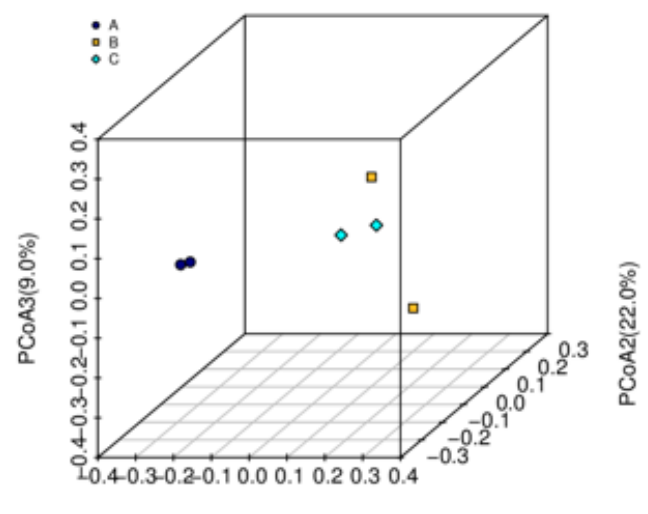

PCoA1 $168.0 \%)$

Figure 7. Analysis of PCA Based on OTU 


\subsection{Pic Rust Function Analysis}

After analyzing the gene function of the existing sequenced microbial genome, we can speculate the composition of the functional genes in the samples by $16 \mathrm{~s}$ sequencing, so as to analyze the functional differences between different samples and groups. Heatmap can reflect the abundance information of the function by color change, and can intuitively express the functional abundance value with the defined color depth. At the same time, the samples and functional information are grouped and rearranged, and the results are displayed in heatmap (Figure 8). The functional analysis of six soil samples from different locations showed that there were five functional pathways with high abundance, which were [G] Carbohydrate transport and metabo, [K] Transcription, [E] Amino acid transport and metabolism, [S] Function unknown, [R] General function prediction only

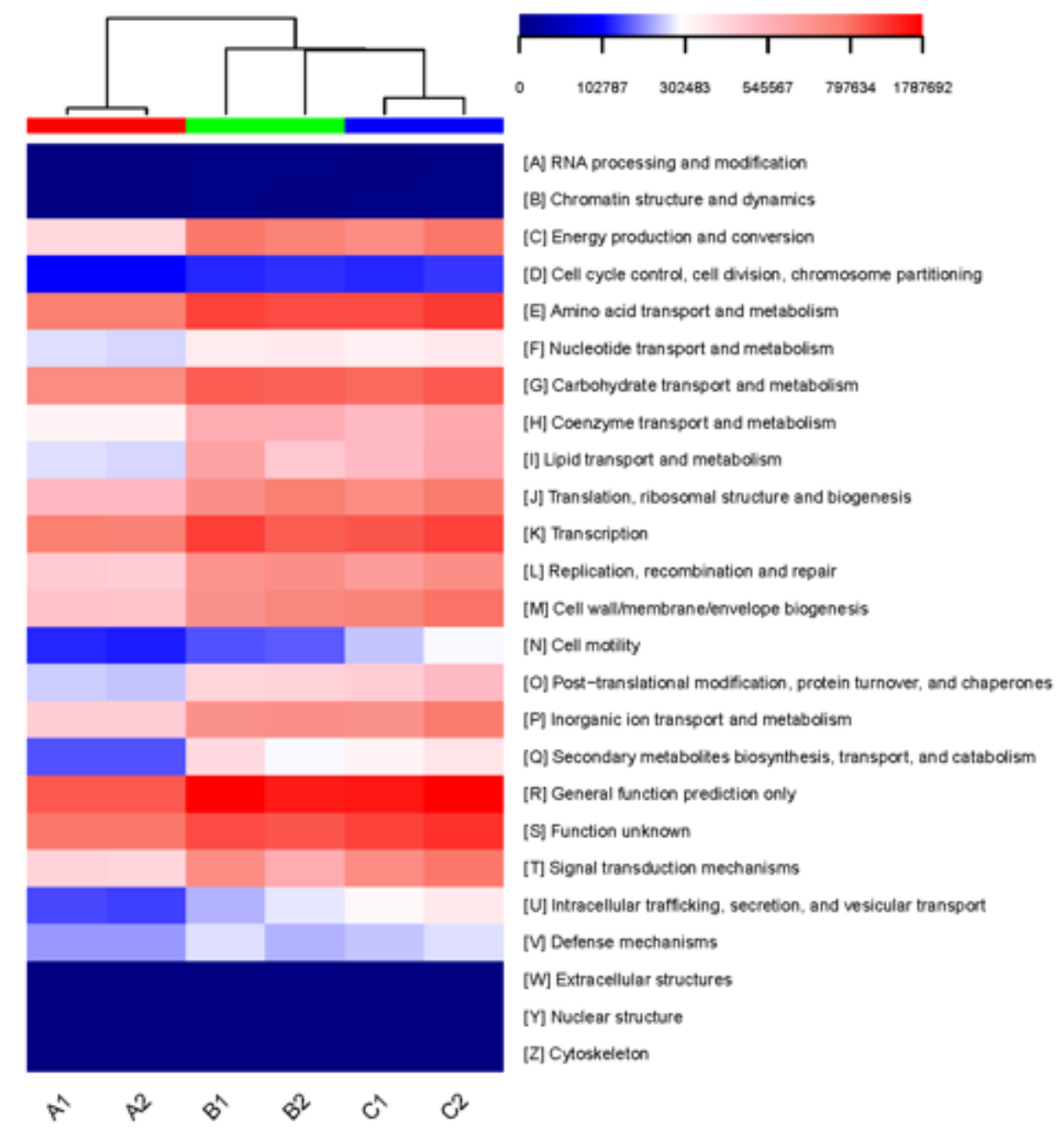

Figure 8. Heatmap of Functional Abundance Based on COG

Note: the heatmap of functional abundance is drawn with functional abundance matrix. Each column represents a sample, the row represents the function, the color block represents the functional abundance value, the redder the color indicates the higher the abundance, the bluer the color is. In addition, the samples were grouped by thermal map, and the closer the distribution of sample flora was, the closer the sample was, and the closer it was in the cluster tree above the graph. There are color blocks at the top of the picture, and the samples from the same group are of the same color.

\section{Effect of Petroleum Hydrocarbon Pollution on the Physical and Chemical Properties of Soil}

In environmental microbial ecology studies, parameters such as $\mathrm{pH}, \mathrm{EC}, \mathrm{SOM}$ and $\mathrm{N}, \mathrm{P}, \mathrm{K}$ are more sensitive to soils contaminated by petroleum hydrocarbons. Therefore, these indicators are often used as a measure of soil pollution or destruction. From the results of physical and chemical properties, there was significant difference in TN, AN, TP, TK, AK in soil samples from different sampling sites $(\mathrm{p}<0.05)$, and there was no significant difference in AP, SOM ( $>0.05)$. The soil is 
affected by oil pollutants, and the carbon content in the soil will increase greatly. Some studies have shown that when $\mathrm{C}: \mathrm{N}: \mathrm{P}=120: 10: 1$ in soil, it is beneficial to the degradation of petroleum pollutants by soil microorganisms [50].

\section{Effects of Petroleum Hydrocarbon Pollution on the Diversity and Community Structure of Soil Microbial Community}

After petroleum hydrocarbon pollutants enter the soil, they first have a serious impact on the composition and quantity of soil microbial community structure in the ecological environment. Different degrees of oil pollution can adapt to the development of soil microbial community structure, and have great differences, forming a more suitable dominant flora for polluting soil environment. There are some differences in microorganisms from different polluted soil environment sources. ALSALEH et al. [47] isolated 272 strains of petroleum-degradable bacteria from the coast of Kuwait, mainly Pseudomonas, Bacillus, Staphylococcus, Acinetobacter, Kocuria and Micrococcus. Among the dominant bacteria isolated from the oil-contaminated soil of Yumen Oilfield, Pseudomonas and Pseudomonas were not only dominant species, but also had obvious degradation effect. The initially reported oil-degrading bacteria were also Pseudomonas bacteria, and there were many reports on their degradation mechanism. The degradation of crude oil by Acinetobacter, Enterobacteriaceae, Salex, Providenes, Delphate and Fibrio has also been reported. From the analysis of the classification level and the phylogenetic tree, the dominant species in soil samples are Bacillus, Lactococcus, Oceanobacillus, and Enterococcus $[48,49]$.

\section{Conclusions}

(1) The genus Rhodococcus of the dominant bacteria isolated from the oil-contaminated soil of the Yumen oilfield is not only dominant in species, but also the degradation effect of the strain is obvious, which is consistent with that of the literature, The genus Rhodococcus is an advantageous bacterium for the separation of many soil and water. The initial report of the oil-degrading bacteria is the bacterium of the genus Pseudomonas, and the mechanism of its degradation is more reported.

(2) The isolated bacteria had different oil degradation ability, among which the degradation rate of 8 strains was not less than $30 \%$ after 7 days of culture, among which the degradation rate of Rhodococcus YM43 was the best, the degradation rate was $55.47 \%$, followed by Acinetobacter YM32 (45.91\%), Enterobacillus YM29 (39.80\%), Rhodococcus YM09 (38.85\%), Micrococcus YM39 (35.75\%), Pseudomonas aeruginosa YM15 (33.84\%),Streptomyces shortwave YM25 (30.98\%) and Serratieae YM20 (30.55\%).

(3) The results of high throughput sequencing showed that the bacteria in the soil belonged to 33 phylum, 48 classes, 78 orders, 179 families and 471 genus. The main advantages of the invention are: the thick-wall fungus door, the deformation fungus door, the pseudo-bacillus door, the actinomycetes door, the green campylobacter and the shuttle-bacillus door, which account for more than $99.00 \%$ of the total amount of the micro-organisms in the sample. The main dominant species are: Bacillus, Lactococcus, Marine, Enterococcus, Citrobacter, Streptococcus, Pteroides, Pseudomonas, Dietchella, Nocardia, Arthrobacter, Streptomyces, Neisseria, Microbacterium, cilia, Haemophilus, Clostridium, Micrococcus, and Acinetobacter. and the analysis found that the common oil-degrading bacteria are, for example, Bacillus, Pseudomonas, Rhodococcus, Acinetobacter, Staphylococci, Lactobacillus, Flavobacterium, Actinomyces, Serratia, Achromobacter, Abasophilic, and Dietchella, Of the genus Arthrospira, the genus Streptomyces, the genus Bacillus, the genus Bacillus, and the genus Pseudomonas, etc., are present in the oil-contaminated soil of Yumen.

Acknowledgements: We acknowledge financial support by National Natural Science Foundation of China (No. 31760028), and the Youth talent support program of Lanzhou University and Technology (No. 2018). 


\section{References}

1WANG, H., ZHONG, H., BO, G., Existing forms and changes of nitrogen inside of horizontal subsurface constructed wetlands. Environ. Sci. Poll. Res., 25(1), 2018, 771-781.

2.WANG, H., AN, X., ZHANG, Z., Effect of advanced treatment on ammonia nitrogen contained in secondary effluent from wastewater treatment plant. Fresenius. Environ. Bull., 27(4), 2018, 20432050.

3.GU, F., GUO, J., ZHANG, W., SUMMERS, P. A., HALL, P., From waste plastics to industrial raw materials: A life cycle assessment of mechanical plastic recycling practice based on a real-world case study. Sci. total. Environ., 601, 2017, 1192-1207.JIAO, S., LIU, Z., LIN, Y., YANG, J., CHEN, W., WEI, G., Bacterial communities in oil contaminated soils: Biogeography and co-occurrence patterns. Soil. Biolog. Biochem., 98, 2016, 64-73.

4.ANDERSON, R. E., SOGIN, M. L., BAROSS, J. A., Biogeography and ecology of the rare and abundant microbial lineages in deep-sea hydrothermal vents. FEMS. Microbiol. Ecol., 91(1), 2015,111.

5.WOLIŃSKA, A., KUŹNIAR, A., SZAFRANEK-NAKONIECZNA, A., JASTRZĘBSKA, N., ROGUSKA, E., STĘPNIEWSKA, Z., Biological activity of autochthonic bacterial community in oil contaminated soil. Water. Air. Soil. Pollut., 227, 2016, 130.

6.Kimes, N. E., Callaghan, A. V., Suflita, J. M., Morris, P. J., Microbial transformation of the Deepwater Horizon oil spill-past, present, and future perspectives. Front. Microbiol., 5, 2014, 603.

7.QAYYUM S., KHAN I., MENG K., ZHAO Y., PENG C., A review on remediation technologies for heavy metals contaminated soil. Cent. Asian. J. Environ. Sci. Technol. Innov., 1(1), 2020, 21-29.

8.BRODKORB, T. S., LEGGE, R. L., Enhanced biodegradation of phenanthrene in oil tarcontaminated soils supplemented with Phanerochaete chrysosporium. Appl. Environ. Microbiol., $\mathbf{5 8}(9), 1992,3117$.

9.PENG, M., ZI, X., WANG, Q., Bacterial Community diversity of oil-contaminated soils assessed by high throughput sequencing of 16S rRNA genes. Int. J. Environ. Res. Public. Health., 12(10), 2015, 12002-12015.

10.WATANABE, K., KODAMA, Y., HAMAMURA, N., KAKU, N., Diversity, abundance, and activity of archaeal populations in oil-contaminated groundwater accumulated at the bottom of an underground crude oil storage cavity. Appl. Environ. Microbiol., 68(8), 2002, 3899-3907.

11.CUNNINGHAM, S. D., BERTI, W. R., HUANG, J. W., Phytoremediation of contaminated soils[J]. Trends. Biotechnol., 13, 1995, 393-397.

12.STECKEL, L. E., SIMMONS, F. W., SPRAGUE, C. L., Soil Factor Effects on Tolerance of Two Corn (Zea mays) Hybrids to Isoxaflutole Plus Flufenacet, Weed. Technol., 17(3), 2003, 599-604.

13.GAO, W., WANG, Y., WANG, W., SHI, L., The first multiplication atom-bond connectivity index of molecular structures in drugs. Saudi. Pharm. J., 25(4), 2017, 548-555.

14.GAO, W., WANG, Y., BASAVANAGOUD, B., JAMIL, M. K., Characteristics studies of molecular structures in drugs. Saudi. Pharm. J., 25(4), 2017, 580-586.

15.LIANG, Y., LIN, Q., HUANG, P., WANG, Y., LI, J., ZHANG, L., CAO, J., Rice Bioactive Peptide Binding with TLR4 To Overcome H2O2-Induced Injury in Human Umbilical Vein Endothelial Cells through NF-кB Signaling. J. Agri. Food. Chem., 66(2), 2018, 440-448.

16.WANG, L., LIN, Q., YANG, T., LIANG, Y., NIE, Y., LUO, Y., LUO, F., Oryzanol modifies high fat diet-induced obesity, liver gene expression profile, and inflammation response in mice. J. Agri. Food. Chem., 65(38), 2017, 8374-8385.

17.NNAEMEKA A. N., Environmental pollution and associated health hazards to host communities (Case study: Niger delta region of Nigeria). Cent. Asian. J. Environ. Sci. Technol. Innov., 1(1), 2020, 30-42.

18.SHIMADA, T., GUENGERICH, F. P., Inhibition of Human Cytochrome P450 1A1-, 1A2-, and 1B1-Mediated Activation of Procarcinogens to Genotoxic Metabolites by Polycyclic Aromatic Hydrocarbons. Chem. Res. Toxicol., 19(2), 2006, 288-294. 
19.NIE, Y., LUO, F., LIN, Q., Dietary nutrition and gut microflora: A promising target for treating diseases. Trends. Food. Sci. Technol., 75, 2018, 72-80.

20.ZHU, B., SU, B., LI, Y., Input-output and structural decomposition analysis of India's carbon emissions and intensity, 2007/08-2013/14. Appl. Energy, 230, 2018, 1545-1556.

21.GUO, J., ZHANG, X., GU, F., ZHANG, H., FAN, Y., Does air pollution stimulate electric vehicle sales? Empirical evidence from twenty major cities in China. J. Clean. Prod., 249, 2020, 119372.

22.GU, F., GUO, J., YAO, X., SUMMERS, P. A., WIDIJATMOKO, S. D., HALL, P., An investigation of the current status of recycling spent lithium-ion batteries from consumer electronics in China. J. Clean. Prod., 161, 2017, 765-780.

23.WANG, G., LEVY, D. D., SEIDMAN, M. M., GLAZER, P. M., Targeted mutagenesis in mammalian cells mediated by intracellular triple helix formation. Mol. Cell. Biol., 15(3), 1995, 17591768.

24.PETERSON, C. H., Long-Term Ecosystem Response to the Exxon Valdez Oil Spill. Science, 302(5653), 2003, 2082-2086

25.ZAPPI, M. E., ROGERS, B. A., TEETER, C. L., GUNNISON, D., BAJPAI, R., Bioslurry treatment of a soil contaminated with low concentrations of total petroleum hydrocarbons. J. Hazard. Mater., 46(1), 1996, 1-12.

26.DIAS, R. L., RUBERTO, L., HERNÁNDEZ, E., VÁZQUEZ, S. C., BALBO, A. L., DEL PANNO, M. T., MAC CORMACK, W. P., Bioremediation of an aged diesel oil-contaminated Antarctic soil: evaluation of the "on site" biostimulation strategy using different nutrient sources. Int. Biodeter. Biodegr., 75, 2012, 96-103.

27.SOUZA, E. C., VESSONI-PENNA, T. C., DE SOUZA OLIVEIRA, R. P., Biosurfactant enhanced hydrocarbon bioremediation: an overview. Int. Biodeter. Biodegr., 89, 2014, 88-94.

28.LIEBEG, E. W., CUTRIGHT, T. J., The investigation of enhanced bioremediation through the addition of macro and micro nutrients in a PAH contaminated soil. Int. Biodeter. Biodegr., 44, 1999, 55-64.

29.ROLLINS, D. M., COLWELL, R. R., Viable but nonculturable stage of Campylobacter jejuni and its role in survival in the natural aquatic environment. Appl. Environ. Microbiol., 52(3), 1986, 531.

30.YATEEM, A., BALBA, M. T., EL-NAWAWY, A. S., AL-AWADHI, N., Experiments in phytoremediation of Gulf War contaminated soil. Soil. Groundw. Clean., 2, 1999, 31-33.

31.MUKHERJEE, A. K., BORDOLOI, N. K., Bioremediation and reclamation of soil contaminated with petroleum oil hydrocarbons by exogenously 379 seeded bacterial consortium: a pilot-scale study. Environ. Sci. Pollut. Res., 18, 2011, 471-478.

32.COULON, F., BRASSINGTON, K. J., BAZIN, R., LINNET, P. E., THOMAS, K. A., MITCHELL, T. R., LETHBRIDGE, G., SMITH, J. W. N., POLLARD, S. J. T., Effect of fertilizer formulation and bioaugmentation on biodegradation and leaching of crude oils and refined products in soils. Environ. Technol., 33, 2012, 1879-1893.

33.SHADE, A., JONES, S. E., CAPORASO, J. G., HANDELSMAN, J., KNIGHT, R., FIERER, N., GILBERT, J. A., Conditionally Rare Taxa Disproportionately Contribute to Temporal Changes in Microbial Diversity. mBio., 5(4), 2014, 1-14.

34.FIERER, N., JACKSON, R. B., The diversity and biogeography of soil bacterial communities. Proc. Natl. Acad. Sci., 103(3), 2006, 626-631.

35.MARCHANT, R., SHARKEY, F. H., BANAT, I. M., RAHMAN, T. J., PERFUMO, A., The degradation of n-hexadecane in soil by thermophilic geobacilli. FEMS Microbiol. Ecol., 56(1), 2006, 44-54.

36.HARTMANN, M., FREY, B., MAYER, J., MADER, P., WIDMER, F., Distinct soil microbial diversity under long-term organic and conventional farming. ISME J., 9, 2015, 1177-1194.

37.THERON, J., CLOETE, T. E., Molecular Techniques for Determining Microbial Diversity and Community Structure in Natural Environments. Crit. Rev. Microbiol., 26(1), 2000, 37-57.

38.LAUREYS, D., DE VUYST, L., Microbial Species Diversity, Community Dynamics, and 
Metabolite Kinetics of Water Kefir Fermentation. Appl. Environ. Microbiol., 80(8), 2014, 2564-2572. 39.KOCHLING, T., SANZ, J. L., GAVAZZA, S., FLORENCIO, L., Analysis of microbial community structure and composition in leachates from a young landfill by 454 pyrosequencing. Appl. Microbiol. Biotech., 99(13), 2015, 5657-5668.

40.TRIVEDI, P., HE, Z., VAN NOSTRAND, J. D., ALBRIGO, G., ZHOU, J., WANG, N., Huanglongbing alters the structure and functional diversity of microbial communities associated with citrus rhizosphere. ISME. J., 6(2), 2012, 363-383.

41.HUESEMANN, M. H., Predictive Model for Estimating the Extent of Petroleum Hydrocarbon Biodegradation in Contaminated Soils. Environ. Sci. Technol., 29(1), 1995, 7-18.

42.EDGAR, R. C., UPARSE: highly accurate OTU sequences from microbial amplicon reads. Nat. Methods., 10(10), 2013, 996-998 .

43.XU, Z., CHEN, X., MENG, L., YU, M., LI, L., SHI, W., Sample Consensus Model and Unsupervised Variable Consensus Model for Improving the Accuracy of a Calibration Model. Appl. Spectroscope., 73(7), 2019, 747-758.

44.NI, J., LI, X., HE, Z., XU, M., A novel method to determine the minimum number of sequences required for reliable microbial community analysis. J. Microbiol. Methods., 137(8), 2017, 196-201.

45.KRISHNA, P., BABU, A. G., REDDY, M. S., Bacterial diversity of extremely alkaline bauxite residue site of alumina industrial plant using culturable bacteria and residue 16S rRNA gene clones. Extrem., 18(4), 2014, 665-676.

46.PŁAZA, G., NALECZ-JAWECKI, G., ULFIG, K., BRIGMON, R. L., The application of bioassays as indicators of petroleum-contaminated soil remediation. Chemosphere., 59(2), 2005, 0296.

47.AL-SAlEH, E., DROBIOVA, H., OBUEKWE, C., Predominant culturable crude oil-degrading bacteria in the coast of Kuwait. Int. Biodeter. Biodegr., 63(4), 2009, 400-406

48.JAIN, P. K., GUPTA, V. K., PATHAK, H., LOWRY, M., JAROLI, D. P., Characterization of 2T engine oil degrading indigenous bacteria, isolated from high altitude (Mussoorie), India. World $J$. Microbiol. Biotechnol., 26(8), 2010, 1419-1426.

49.LUO, Q., ZHANG, J. G., SHEN, X. R., FAN, Z. Q., HE, Y., HOU, D. Y., Isolation and characterization of marine diesel oil-degrading Acinetobacter sp strain Y2 . Ann. Microbiol., 62(2), 2013, 633-640.

50.MAN, Z., EBADI, A. G., MOSTAFAVI, S. M., SURENDAR, A., Fuel oil characteristics and applications: economic and technological aspects. Petrol. Sci. Technol., 37(9), 2019, 1041-1044.

$\overline{\text { Manuscript received: } 14.03 .2020}$ 